\title{
Effect of Caffeine on Some Selected Biochemical Parameters Using Rat Model
}

\author{
Agomuo Emmanuel, ${ }^{1}$ Duru Majesty, ${ }^{2}$ Amadi Benjamin, ${ }^{3}$ \\ Amadi Peter, ${ }^{3}$ and Ugwokaegbe Princess ${ }^{2}$ \\ ${ }^{1}$ Department of Biochemistry, Imo State University, Owerri, Imo State, Nigeria \\ ${ }^{2}$ Department of Chemical Sciences (Biochemistry Unit), Rhema University, Aba, Abia State, Nigeria \\ ${ }^{3}$ Department of Biochemistry, University of Port Harcourt, Choba, Rivers State, Nigeria
}

Correspondence should be addressed to Duru Majesty; kelechukwuduru@gmail.com

Received 30 April 2016; Revised 14 September 2016; Accepted 4 October 2016; Published 19 January 2017

Academic Editor: Byung-Cheon Lee

Copyright (C) 2017 Agomuo Emmanuel et al. This is an open access article distributed under the Creative Commons Attribution License, which permits unrestricted use, distribution, and reproduction in any medium, provided the original work is properly cited.

Effect of caffeine on some selected biochemical parameters using rat model was investigated. Standard methods of analysis were used for the study. A total of sixty (60) rats divided equally into five groups of which one group served as the control, and the rest as test groups were used. The test rats were placed on different concentrations of caffeine for twenty-eight (28) days. Results obtained for the selected biochemical parameters revealed that AST and ALT levels of the liver increased significantly $(p<0.05)$ in test rats against the control. Creatinine and electrolyte ions of the kidney increased significantly $(p<0.05)$ in test groups when compared to the control. Haematological indices such as WBC, monocytes, lymphocytes, MCV, MCHC, and MCV levels were significantly altered $(p<0.05)$ in test rats against those of the control. It therefore becomes imperative for those that consume caffeine with believe that it does more good work than harm to take note of these findings. This study has revealed the effect of caffeine on some selected biochemical parameters using rat model.

\section{Introduction}

It is on record that so many bioactive compounds found in plants have been useful to both plants and animals [18]. Some of these useful compounds have been industrially synthesized and used in different ways to meet up with the supposed effects of the natural form of the compounds in living organisms. Records have it that the productions of most consumable products are done with the naturally extracted products of these compounds or their synthetic analogue. Natural compounds found in plants or their synthetic forms, for instance, are the basis of modern pharmacopeia [9].

Since ages past, caffeine has been among such bioactive compounds with the quality of being used in its natural or synthetic form [6-11]. Caffeine (chemically, 1,2,3trimethylxanthine) is a white crystalline xanthine alkaloid, which is bitter in taste $[4,5]$. It is an alkaloid compound naturally found in tea leaves, cocoa beans, nuts such as bitter kola and kola nut, and fruits of more than sixty plants $[5,6]$. Industrially, extract of caffeine is used in the production of soft drinks, coffee, and tea and in some processed foods [1215]. In medicine, it is chiefly a psychoactive drug used for nervous system stimulation [16]. Nawrot et al. [9] noted that caffeine is probably the most frequently ingested pharmacologically active substance in the world, found in common beverages (coffee, tea, and soft drinks), products containing cocoa or chocolate, medications including headache or pain remedies, and over-the-counter stimulants [17]. The wide use of caffeine in productions and its increasing world consumption could be the reason why little or no effort has been made to set aside the existing controversy surrounding the conflicting results generated by the use of variable forms of caffeine and experimental methods towards the study of its possible toxicity [18].

Despite the report of Pearson and Nadeau [18], who noted the physiological effects of caffeine in rat and extracellular 
cyclic AMP status, growth pattern, and glucose metabolism in adipose tissue, different school of thought still believes that caffeine does more beneficial work than harm in living organisms. The present study aimed at setting aside the controversies surrounding the toxicity of caffeine in living organism and investigated its effect on some selected biochemical parameters using rat model.

\section{Materials and Methods}

2.1. Procurement and Preparation of Caffeine Sample. Caffeine sample used in this study was procured from Nigerian breweries PLC, Aba Depot, Nigeria. Doses of caffeine prepared and used for this study were $50 \mathrm{mg} / \mathrm{kg}, 100 \mathrm{mg} / \mathrm{kg}$, $190 \mathrm{mg} / \mathrm{kg}$, and $300 \mathrm{mg} / \mathrm{kg}$ body weight (BW) of rats.

2.2. Experimental Animals and Research Design. A total of sixty (60) male albino rats of Wistar strain weighing between 100 and $130 \mathrm{~g}$ were purchased from animal colony of the Department of Biochemistry, Abia State University, Uturu, Nigeria, and kept in standard cages for 7 days to enable them acclimatize to their new environment. Pelletized commercial rat feed (Pfizer livestock Co. Ltd., Aba, Nigeria) and potable water were given to the rats ad libitum within this period. The study was approved by the Animal Welfare and Ethics Committee of Rhema University, Aba, Nigeria, with the reference number (RHEMA/DEC/BCH/001). All conditions of animal use were adhered to as obtained from National Institute of Health (NIH) Guide for Care and Use of Laboratory Animals [19]. After acclimatization period, the rats were allocated to five groups of twelve rats each designated as control group and groups I, II, III, and IV. Groups I-IV served as the experimental test rats. The weights of the rats were equalized as nearly as possible. The rats' treatments lasted for twenty-eight (28) days.

The treatments given to the rats are stated as follows:

$$
\begin{aligned}
& \text { Control group: normal saline + feed + water } \\
& \text { Group I: } 50 \mathrm{mg} / \mathrm{kg} \mathrm{BW} \text { of caffeine + feed + water } \\
& \text { Group II: } 100 \mathrm{mg} / \mathrm{kg} \mathrm{BW} \text { of caffeine + feed + water } \\
& \text { Group III: } 190 \mathrm{mg} / \mathrm{kg} \mathrm{BW} \text { of caffeine + feed + water } \\
& \text { Group IV: } 300 \mathrm{mg} / \mathrm{kg} \text { BW of caffeine + feed + water }
\end{aligned}
$$

2.3. Blood Sample Collection. At the end of administration period (28 days), rats from various groups were reweighed, anaesthetized with chloroform vapor, and dissected. Blood was collected by cardiac puncture into clean tubes for hepatic and kidney function tests while the ones for haematological indices were collected into anticoagulant tubes. The tubes were properly labeled and used for analysis.

2.4. Serum Assay. The serum assays undertaken were those of liver and kidney function tests. The level of alkaline phosphatase (ALP) was determined by the method of Write et al. [20]. Alanine aminotransferase (ALT) and aspartate aminotransferase (AST) were determined as described by Reitman and Frankel [21]. The assay of bilirubin both total and conjugated was carried out using the method of Jendrassik and Groff [22]. Urea estimation was done using UreaseBerthlot method. Potassium ion was determined by direct spectrophotometric method. Bicarbonate was determined using Forrester et al. [23] method. Creatinine was estimated using the method described by Heinegård and Tiderström [24]. Sodium ion and chloride ion levels were determined according to the instructions on their diagnostic kits purchased from Randox laboratories (UK).

2.5. Haematological Analysis. The autoanalyzer machine was used for hematological analysis. The blood samples contained in the anticoagulant tubes were swirled/rolled on the blood roller each for five seconds and then opened and put under the probe of the autoanalyzer. The probe then collected the blood from the tubes for about 10 seconds and entered back into the haematology machine. The result was then printed a few seconds later, giving the parameters white blood cells (WBC), red blood cells (RBC), haemoglobin ( $\mathrm{Hb})$, lymphocytes (LY), monocytes (MO), mean corpuscular volume (MCV), mean corpuscular haemoglobin (MCH), and mean corpuscular haemoglobin concentration (MCHC). PCV was estimated using microhaematocrit methods as described by Alexander and Griffiths [25].

2.6. Statistical Analysis. Results were presented as mean and standard deviations of triplicate determinations. Group comparisons were done using the least significant difference (LSD). Significant difference was established at 5\% level as described by Onu and Igwemma [26].

\section{Results and Discussion}

Toxic materials cause peroxidative degradation in the adipose tissue resulting in infiltration of the hepatocytes $[27,28]$. Results of serum alanine aminotransferase (ALT) and aspartate aminotransferase (AST) as presented in Figures 1 and 2, respectively, revealed significant increase $(p<0.05)$ of the enzymes in test groups against the control group. It has been reported that tissue damage is usually associated with the release of enzymes specific to the affected tissues or organs in circulation [29, 30]. According to Uboh [31] cell derived enzymes have high activity in the cells and only spill into the plasma when the cells are damaged or enzymes produced in excess. According to Ranjna [32], both AST and ALT enzymes are excellent markers of liver damage caused by exposure of liver to toxic substances. However, ALT is more specific liver enzyme for diagnostic use when the integrity of the hepatocellular membrane is compromised [33]. The increased transaminase levels of test rats against the control as observed in the present study could be linked to consumption of caffeine. The mechanism behind the enzymes leakage could be linked to the peroxidative effect of caffeine in fatty liver tissue in rats as reported by Dianzani et al. [34].

This observation is in line with the works of Casiglia et al. [35] and Manne and Saab [36]. The significant increase in ALT activity among test groups as observed in the present study could be evidence of hepatotoxicity cause by caffeine. According to Uboh [31], alkaline phosphatase (ALP) occurs 


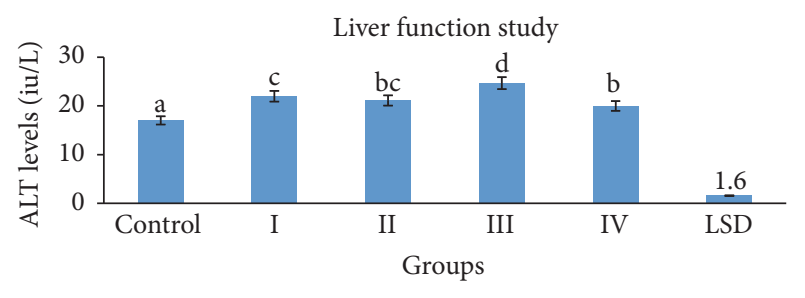

ALT

FIGURE 1: ALT level of rats. LSD: least significant difference and ALT: alanine aminotransferase. Bars with different letters of alphabets have values that are statistically significant $(p<0.05)$.

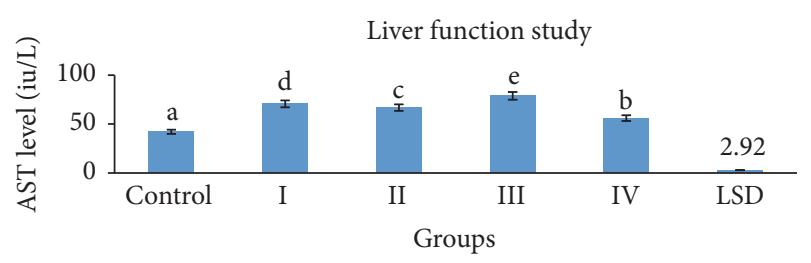

AST

FIGURE 2: AST level of rats. LSD: least significant difference and AST: aspartate aminotransferase. Bars with different letters of alphabets have values that are statistically significant $(p<0.05)$.

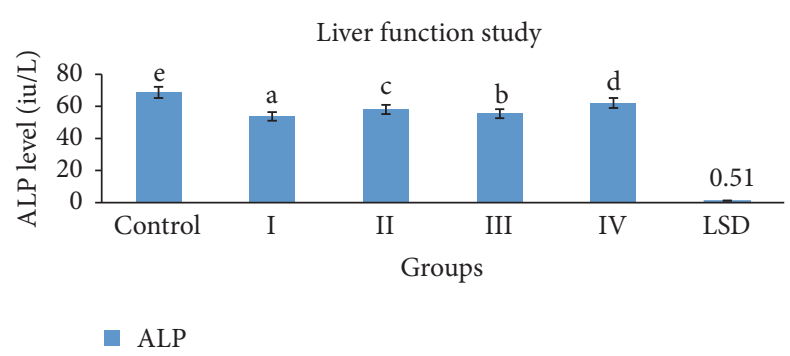

FIgURE 3: ALP level of rats. LSD: least significant difference and ALP: alkaline phosphatase. Bars with different letters of alphabets have values that are statistically significant $(p<0.05)$.

in the liver next to bile ducts and in the bone. It leaks to the blood stream in a manner similar to that of ALP and AST and has been associated with the prostate [37]. ALP levels of the present study followed a decreasing order when compared to the control. The observed decrease was significant $(p<0.05)$ in test groups against the control (Figure 3). This observation is in line with earlier works of Urgert et al. [38] and Fried [39] that reported similar decrease in rats placed on filtered and unfiltered caffeine but not in line with the observation of Salahdeen et al. [40]. It has been hypothesized that liver enzymes are a target for caffeine or other components of coffee [37]. Apart from the total bilirubin level of group I $(50 \mathrm{mg} / \mathrm{kg} \mathrm{BW})$, bilirubin levels for other test groups (both total and conjugated) were significantly $(p<0.05)$ reduced when compared to the control in this study (Figures 4 and $5)$. However, since the levels were within bilirubin acceptable range of $0.2-1.2 \mathrm{mg} / \mathrm{dl}$, the observed decrease is too small and could not be linked with cholestatic disease [41].

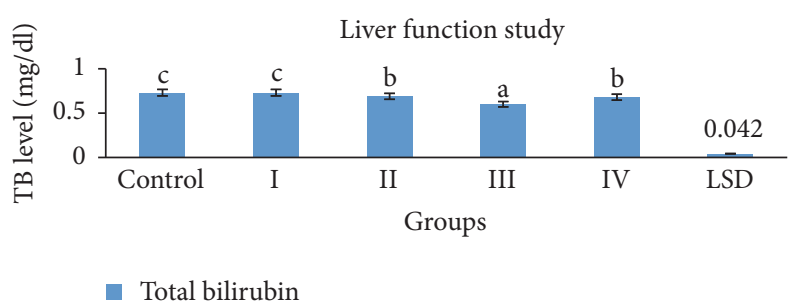

FIGURE 4: Total bilirubin of rats. LSD: least significant difference and TB: total bilirubin. Bars with different letters of alphabets have values that are statistically significant $(p<0.05)$.

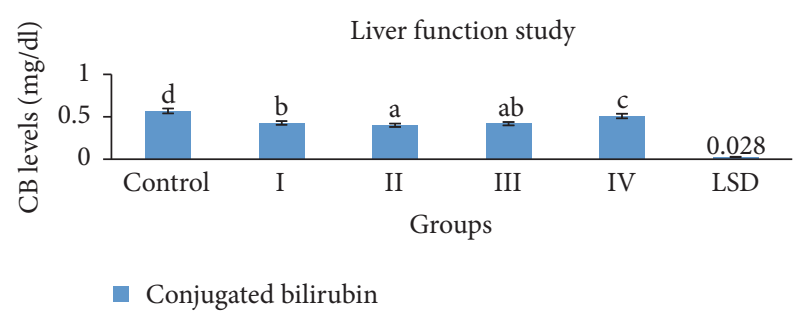

FIGURE 5: Conjugated bilirubin of rats. LSD: least significant difference and CB: conjugate bilirubin. Bars with different letters of alphabets have values that are statistically significant $(p<0.05)$.



FIGURE 6: Urea level of rats. LSD: least significant difference. Bars with different letters of alphabets have values that are statistically significant $(p<0.05)$.

The observed decrease in bilirubin levels in the present study agree with the earlier work of Aloy-Amadi et al., [42] who reported a decrease in bilirubin levels following intake of strong unfiltered coffee.

Different authors have noted that assessment of levels of excretory metabolites such as electrolyte, urea, and creatinine can be used to evaluate renal function $[43,44]$. Urea is the main end product of protein catabolism [45]. Amino acid deamination takes place in the liver, which is also the site of urea cycle where ammonia released is converted into urea and is excreted through urine $[43,46,47]$. Urea varies directly with protein intake and inversely with the rate of excretion [44]. According to Ranjna [32], renal diseases which diminish the glomerular filtration lead to urea retention. Creatinine is a waste product of muscle by creatine metabolism. Its retention in the blood is evidence of kidney impairment [46]. The observed increase in urea (Figure 6) and creatinine (Figure 7) levels showed significant change $(p<0.05)$, when compared 


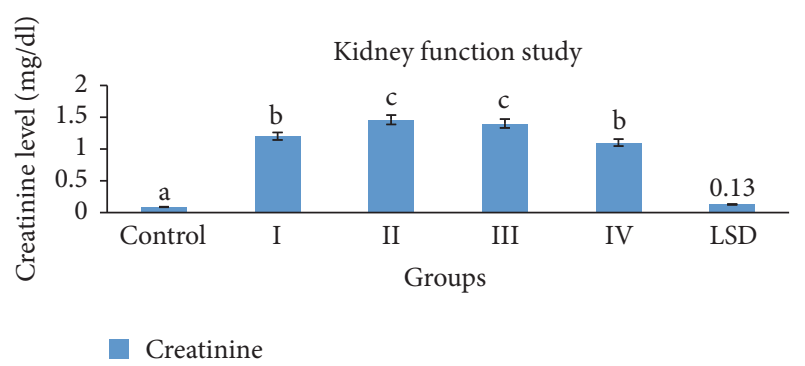

FIGURE 7: Creatinine level of rats. LSD: least significant difference. Bars with different letters of alphabets have values that are statistically significant $(p<0.05)$.

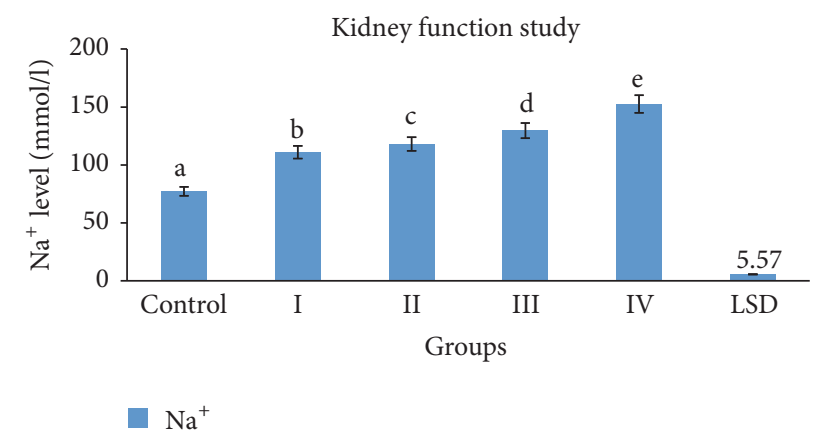

FIGURE 8: $\mathrm{Na}^{+}$level of rats. LSD: least significant difference. Bars with different letters of alphabets have values that are statistically significant $(p<0.05)$.

to control group. This increase suggests that renal function was compromised following the administration of caffeine. The levels of sodium (Figure 8) and potassium (Figure 9) ions increased significantly $(p<0.05)$ in test groups when compared to the control group. The observed increase could mean an effect on both sodium ion and potassium ion pumps of test rats, which could be linked to caffeine administration. The observed increase in sodium ion is in line with the earlier works of Geethanvani and Rameswarudu [48]; Armstrong [49]; Armstrong et al. [50]; and Alves et al. [51]. The increase observed in potassium ion in the present study is in line with the work of Armstrong et al. [50] but does not agree with the earlier works of Shirley et al. [52] and Passmore et al. [53]. The use of serum chloride (Figure 10) and bicarbonate (Figure 11) ions to assess renal functions cannot be overstated. The significant increase $(p<0.05)$ in serum chloride and bicarbonate ions following administration of caffeine at various doses in test rats against the control could be indicative of tubular and glomerular dysfunction.

Assessment of haematology is of diagnostic importance in the routine clinical evaluation of the state of health [54]. It explains the blood relating functions of consumed substances Duru et al. [29]. Yakubu et al. [55] noted that assessment of haematological parameters cannot only be used to determine the extent of deleterious effect of extracts on the blood of an animal, but it can also be used to explain blood relating functions of a plant extract or its products. The observed significant increase $(p<0.05)$ of WBC (Figure 15) in test

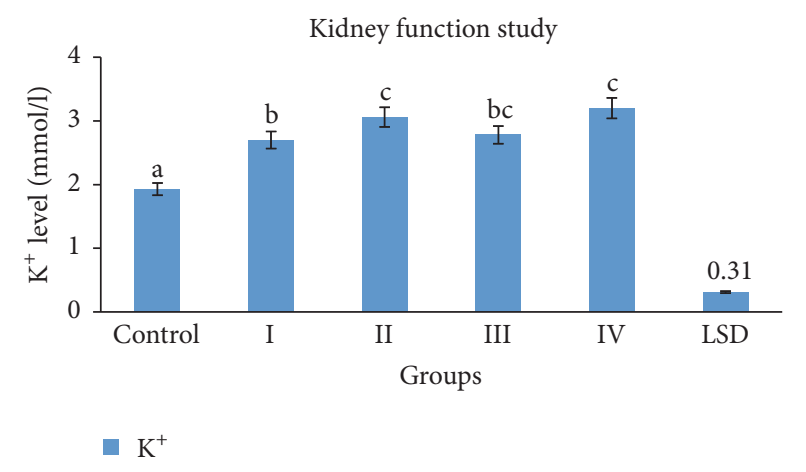

FIGURE 9: $\mathrm{K}^{+}$level of rats. LSD: least significant difference. Bars with different letters of alphabets have values that are statistically significant $(p<0.05)$.

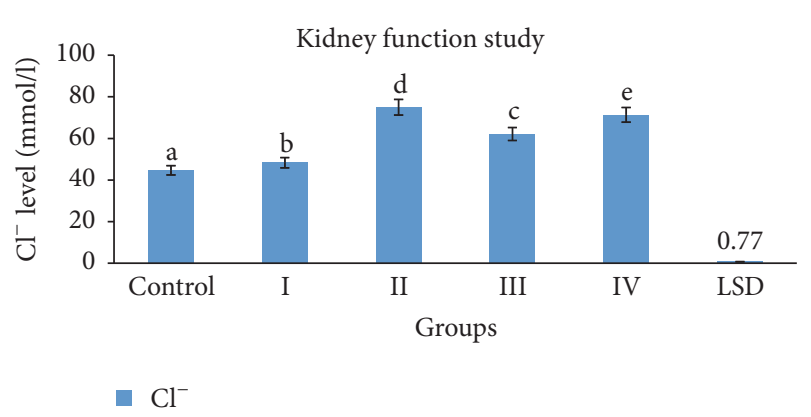

FIGURE 10: $\mathrm{Cl}^{-}$level of rats. LSD: least significant difference. Bars with different letters of alphabets have values that are statistically significant $(p<0.05)$.

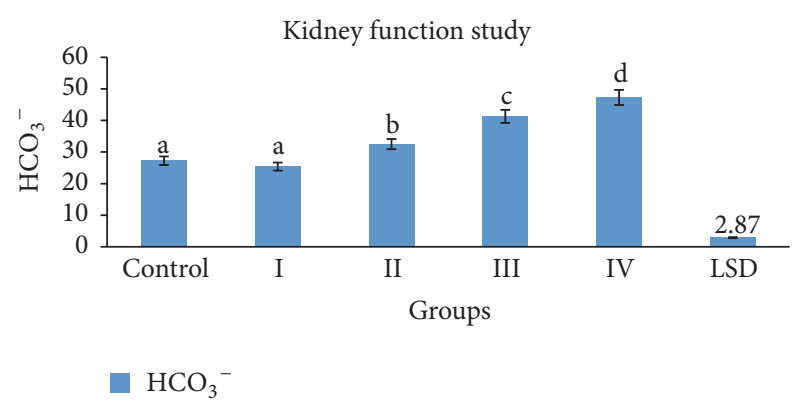

FIGURE 11: $\mathrm{HCO}_{3}{ }^{-}$level of rats. LSD: least significant difference. Bars with different letters of alphabets have values that are statistically significant $(p<0.05)$.

rats when compared to the control could be a clear indication of normal reaction of rats to foreign substances, which alter their normal physiological processes. WBC production known as leukocytosis observed in this study indicates a stimulation of the immune system by the caffeine, which may have protected the rats against any chemical and secondary infection. It has been noted that leukocytosis may be directly proportional to severity of the causative stress condition and may be attributed to an increase in leucocyte mobilization $[56,57]$. Monocyte (Figure 16) and lymphocyte (Figure 17) levels of test rats increased significantly $(p<0.05)$ against the control. This could be attributed to the stimulating effect 


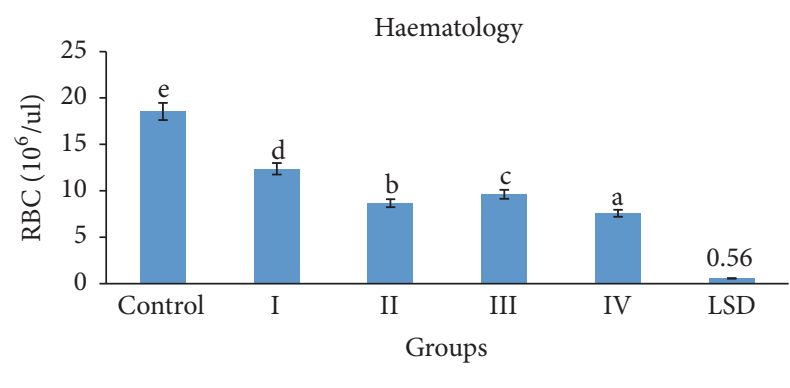

- $\mathrm{RBC}$

FIGURE 12: RBC level of rats. LSD: least significant difference. Bars with different letters of alphabets have values that are statistically significant $(p<0.05)$.

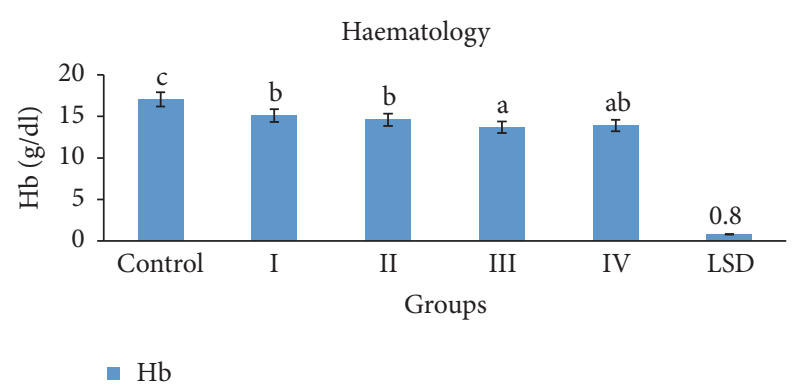

FIGURE 13: Hb level of rats. LSD: least significant difference. Bars with different letters of alphabets have values that are statistically significant $(p<0.05)$.

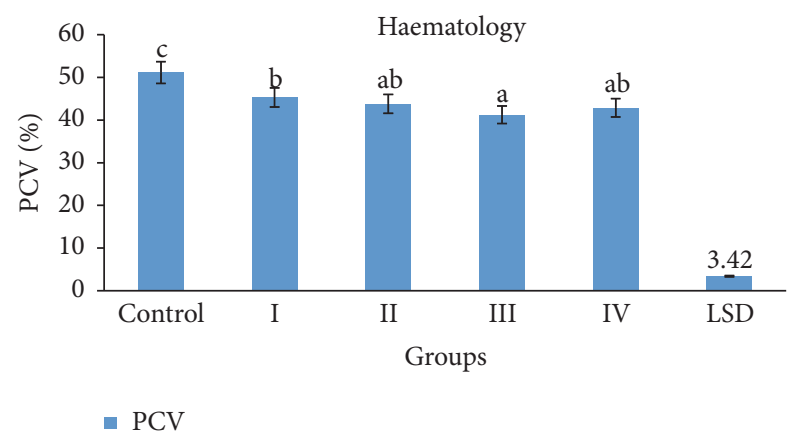

Figure 14: PCV level of rats. LSD: least significant difference. Bars with different letters of alphabets have values that are statistically significant $(p<0.05)$.

of the administered caffeine. The significant reduction $(p<$ 0.05 ) observed in RBC (Figure 12) levels of test rats against the control may be an indication that the balance between the rate of production (erythropoiesis) and destruction of the blood corpuscles was altered. The reduction in PCV (Figure 14) of test rats against the control as observed in the present study could be attributed to its relationship with $\mathrm{Hb}$ (Figure 13) in blood [30]. According to Adebayo et al. [56]; Adebayo et al. [58]; and Duru et al. [29], MCV, MCHC, and $\mathrm{MCH}$ are related to individual red blood cells. MCV (Figure 18), MCHC (Figure 19), and MCH (Figure 20) levels increased significantly $(p<0.05)$ in test rats against the control.

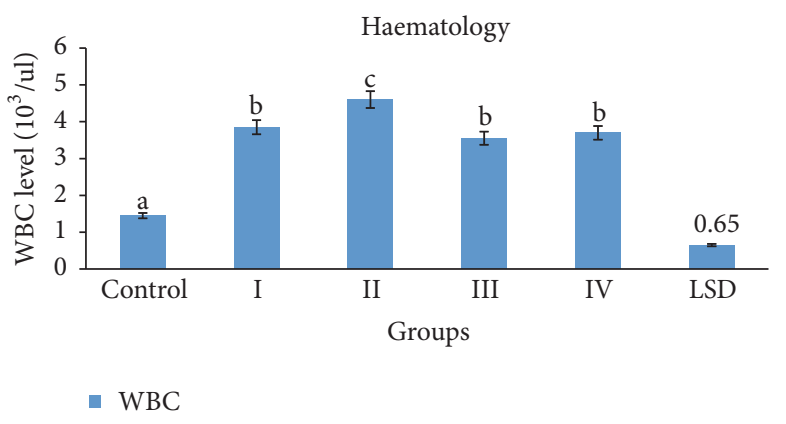

FIGURE 15: WBC level of rats. LSD: least significant difference. Bars with different letters of alphabets have values that are statistically significant $(p<0.05)$.

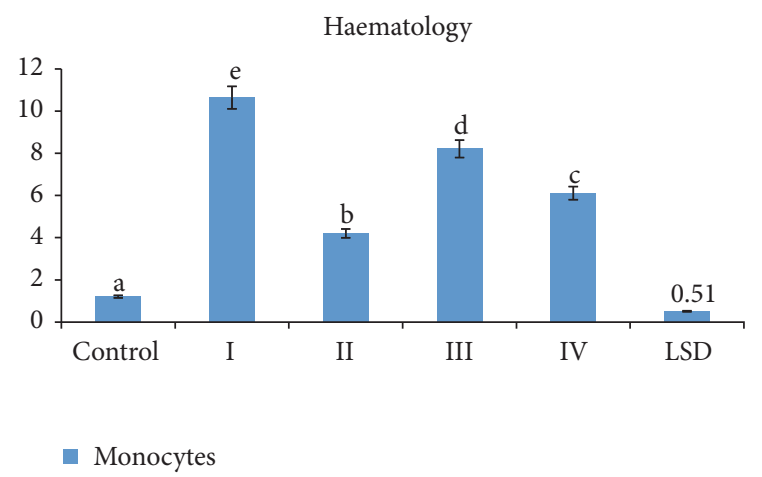

FIGURE 16: Monocytes level of rats. LSD: least significant difference. Bars with different letters of alphabets have values that are statistically significant $(p<0.05)$.

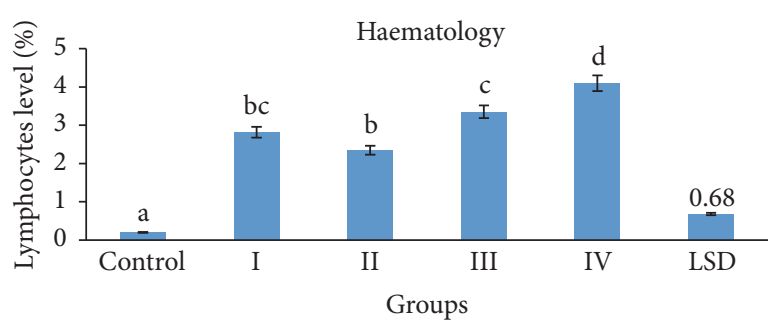

- Lymphocytes

FIGURE 17: Lymphocytes level of rats. LSD: least significant difference. Bars with different letters of alphabets have values that are statistically significant $(p<0.05)$.

The observed increase could mean that incorporation of haemoglobin into red blood cells, the morphology, and osmotic fragility of red blood cells were altered. Hassan et al. [59] and Keele et al. [60] attributed change in $\mathrm{MCH}$ and MCHC to normocytic or hypochromic anaemia. Such anaemic conditions may be possible with consumption of caffeine, since the $\mathrm{MCH}, \mathrm{MCV}$, and $\mathrm{MCHC}$ levels of the test rats were significantly altered in the present study.

Result obtained for body weight studies (Table 1) showed significant $(p<0.05)$ reduction in weight gain and $\%$ weight gain of test rats against those of the control. According to 
TABLE 1: Weight gain and \% weight gain of rats given different concentrations of caffeine for 28 days.

\begin{tabular}{lccccc}
\hline Parameters & Control & Group I & Group II & Group III & Group IV \\
\hline Final weight $(\mathrm{g})$ & $240.11 \pm 9.05$ & $232.18 \pm 8.15$ & $229.95 \pm 7.02$ & $226.17 \pm 4.30$ & $224.81 \pm 10.50$ \\
Initial weight $(\mathrm{g})$ & $197.80 \pm 5.12$ & $198.00 \pm 4.02$ & $198.05 \pm 5.31$ & $198.08 \pm 9.12$ & $198.11 \pm 9.59$ \\
Weight gain $(\mathrm{g})$ & $42.30^{\mathrm{a}}$ & $34.18^{\mathrm{b}}$ & $31.90^{\mathrm{c}}$ & $28.09^{\mathrm{d}}$ & $26.70^{\mathrm{e}}$ \\
\% weight gain $(\%)$ & 25.92 & 20.94 & 19.55 & 17.22 & 16.36 \\
\hline
\end{tabular}

Values with different letters of alphabet along the same row are statistically significant at $5 \%$ level.

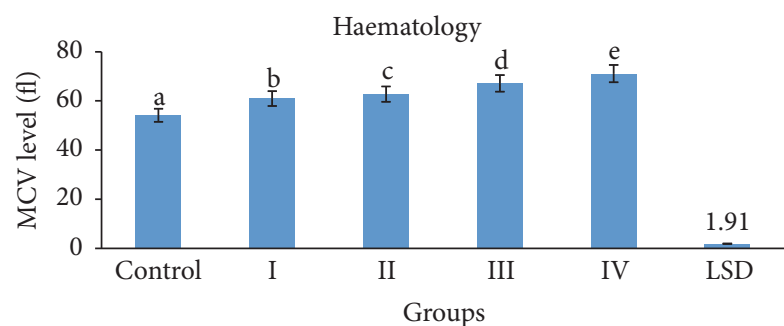

MCV

FIGURE 18: MCV level of rats. LSD: least significant difference. Bars with different letters of alphabets have values that are statistically significant $(p<0.05)$.

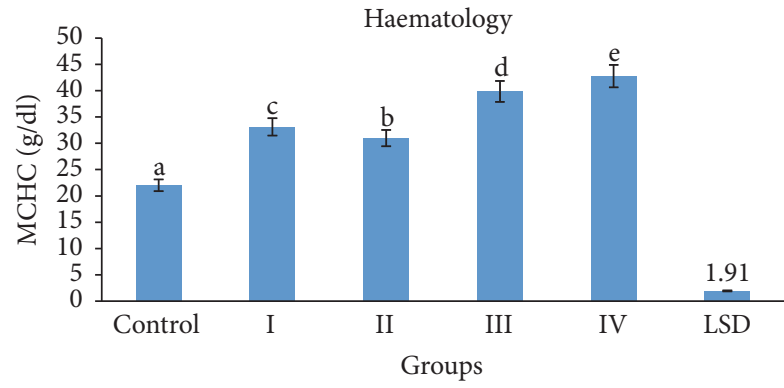

- MCHC

FIGURE 19: MCHC level of rats. LSD: least significant difference. Bars with different letters of alphabets have values that are statistically significant $(p<0.05)$.

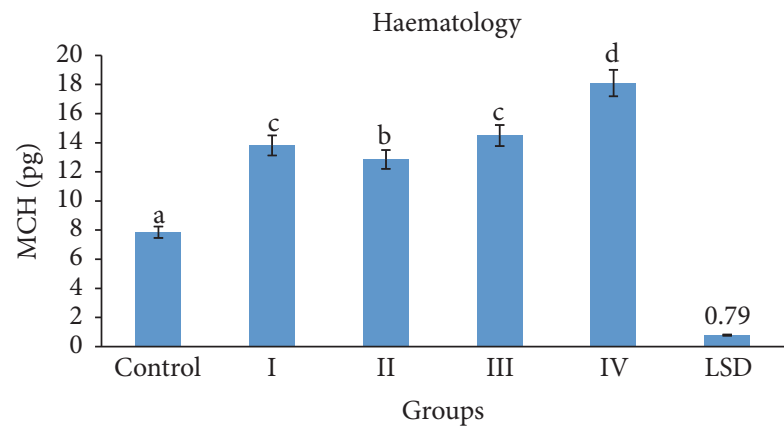

- $\mathrm{MCH}$

FIgURE 20: MCH level of rats. LSD: least significant difference. Bars with different letters of alphabets have values that are statistically significant $(p<0.05)$.
Yehya [61], caffeine stimulates weight loss by increasing the sympathetic tone of various resting tissue beds, notably fat. This observation is in line with the works of Zheng et al. [62]; Cheung et al. [63]; Muroyama et al. [64]; Choi et al. [65]; Han et al. [66]; Naismith et al. [67]; and Würzner et al. [68], who noted that consumption of caffeine has been associated with decrease in body weight of rodents.

\section{Conclusion}

Observations of the present study revealed severe effect of caffeine when administration to rats on liver, kidney, and haematology indices. It also affected their body weight. These observations are in line with some previous studies. There is need for those that consume caffeine with believe that it does more work than harm to take note of these findings.

\section{Competing Interests}

The authors declare that there is no conflict of interests regarding the publication of this paper.

\section{References}

[1] E. N. Agomuo, E. N. Onyeike, E. O. Anosike, and M. K. C. Duru, "Effects of Tetrapleura tetraptera on lipid profiles and mineral concentration of male, female, pregnant and lactating albino rats," Intraspecific Journal of Biochemistry and Biotechnology, vol. 1, no. 1, pp. 1-7, 2014.

[2] D. E. Okwu, "Phytochemical and vitamin content of indigeous spices of South Eastern, Nigeria," Journal Sustain Agriculture, vol. 6, pp. 30-34, 2004.

[3] D. E. Okwu and M. E. Okwu, "Chemical composition of Spondias mombia linn Plant parts," Journal Sustain Agrictural Environment, vol. 6, pp. 140-147, 2004.

[4] H. D. Neuwinger, African Ethnobotanical; Piosons and Drugs, Chapman and Hall, London, UK, 1st edition, 1996.

[5] H. D. Neuwinger, African Traditional Medicine, a Dictionary of Plants Use and Application, Medpharm GmbH Publishers, Stuttgart, Germany, 2000.

[6] M. Iwu, Handbook of African Medicinal Plants, CKC Press, New York, NY, USA, 1993.

[7] A. Sofoware, Medicinal Plants and Traditional Medicine in Africa, Spectrum Books, Ibadan, Nigeria, 1993.

[8] H. M. Burkill, "The useful plants of West Tropical Africa," in Royal Botanical Biochemistry, vol. 2, pp. 441-415, W.H. Garden Kwe, 3rd edition, 1985. 
[9] P. Nawrot, S. Jordan, J. Eastwood, J. Rotstein, A. Hugenholtz, and M. Feeley, "Effects of caffeine on human health," Food Additives and Contaminants, vol. 20, no. 1, pp. 1-30, 2003.

[10] W. Shauna, "Naturally versus synthetic caffeine," http://eco18 .com/naturally-vs-synthetic-caffeine.

[11] O. J. Weinkauff, R. W. Radue, R. Keller, and H. R. Eane, "Caffeine evaluation, identifaction of caffeine as natural or synthetic," Journal of Agric and Food Chemistry, vol. 9, no. 5, pp. 397-340, 1961.

[12] E. M. R. Kovacs, J. H. C. H. Stegen, and F. Brouns, "Effect of caffeinated drinks on substrate metabolism, caffeine excretion, and performance," Journal of Applied Physiology, vol. 85, no. 2, pp. 709-715, 1998.

[13] R. D. Wemple, D. R. Lamb, and K. H. McKeever, "Caffeine vs caffeine-free sports drinks: effects on urine production at rest and during prolonged exercise," International Journal of Sports Medicine, vol. 18, no. 1, pp. 40-46, 1997.

[14] K. Sugiyama, S. Kuriyama, M. Akhter et al., "Coffee consumption and mortality due to all causes, cardiovascular disease, and cancer in Japanese women," Journal of Nutrition, vol. 140, no. 5, pp. 1007-1013, 2010.

[15] L. K. Massey and T. A. Berg, "The effect of dietary caffeine on urinary excretion of calcium, magnesium, phosphorus, sodium, potassium, chloride and zinc in healthy males," Nutrition Research, vol. 5, no. 11, pp. 1281-1284, 1985.

[16] L. L. Spriet, "Caffeine and performance," International Journal of Sport Nutrition, vol. 5, pp. S84-S99, 1995.

[17] C. J. Derry, S. Derry, and R. A. Moore, "Caffeine as an analgesic adjuvant for acute pain in adults," Cochrane Database of Systematic Reviews, no. 3, http://www.thelifestyleelf.net/new-reviewevidence-shows-caffeine-makes-painkillers-more-effective/ \#sthash.6MwYtvj7.dpuf.

[18] S. R. Pearson and M. H. Nadeau, "Physiological effects of caffeine in the rat: extracellular cyclic AMP status, growth pattern and glucose metabolism in adipose tissue," Journal of Nutrition, vol. 111, pp. 658-664, 1981.

[19] NIH, National Research Council Guide for the Care and Use of Laboratory Animals, Publication no. 85-123( rev.), National Institute Health, Bethesda, Md, USA, 1985.

[20] P. J. Write, P. D. Leathwood, and D. T. plummer, "Enzymes in rat urine. Alkaline phosphatase," Enzymology, vol. 42, pp. 31-427, 1972.

[21] S. Reitman and S. Frankel, "A colorimetric method for the determination of serum glutamic oxalacetic and glutamic pyruvic transaminases," American Journal of Clinical Pathology, vol. 28, no. 1, pp. 56-63, 1957.

[22] L. Jendrassik and P. Groff, "Colorimetric method for measurement of Bilirubin," Biochemical Journal, vol. 297, no. 81, 1938.

[23] R. L. Forrester, L. J. Watafe, D. A. Silverman, and K. J. Pierre, "Enzymatic method for the determination of $\mathrm{CO}_{2}$ in serum," Clinical Chemistry, vol. 22, no. 2, pp. 243-245, 1976.

[24] D. Heinegård and G. Tiderström, "Determination of serum creatinine by a direct colorimetric method," Clinica Chimica Acta, vol. 43, no. 3, pp. 305-310, 1973.

[25] R. R. Alexander and J. M. Griffths, Haematocrit in Basic Biochemical Methods, John Wiley \& Sons, New York, NY, USA, 2nd edition, 1993.

[26] M. Onu and A. A. Igwemma, Applied Statistical Techniques for Business and Basic Sciences, Skillmark Media, 2nd edition, 2000.

[27] M. K. C. Duru, B. A. Amadi, C. T. Amadi et al., "Toxic effect of Carica papaya bark on body weight, haematology, and some biochemical parameters," Biokemistri, vol. 24, no. 2, pp. 67-71, 2012.

[28] K. L. Mankani, V. Krishna, B. K. Manjunatha et al., "Evaluation of hepatoprotective activity of stem bark of Pterocarpus marsupium Roxb," Indian Journal of Pharmacology, vol. 37, no. 3, pp. 165-168, 2005.

[29] M. K. C. Duru, E. N. Agomuo, and B. A. Amadi, "Biochemical studies on 'Udu' an antimalarial concoction used in Umunchi village, Isiala Mbano L.G.A of Imo State, Nigeria," Continental Journal of Pharmacology and Toxicology Research, vol. 5, no. 2, pp. 28-34, 2012.

[30] A. Mathew, "Liver enzymes (elevated)," in Principles of Health Choice, Media Inc, 2001, http://www.liverenzyme.com/.

[31] F. E. Uboh, "Clinical uses of enzymes," in Conceptual Enzymology, pp. 190-212, Innolex Printers and Publishers, Calabar, Nigeria, 2004.

[32] C. Ranjna, Practical Clinical Biochemistry Methods and Interpretation, 2nd edition, 1999.

[33] D. W. Moss and A. R. Henderson, "Enzymes," in Tietz Fundamental of Clinical Chemistry, N. W. Tietz, Ed., pp. 283-335, W.B. Saunders, Philadalphia, Pa, USA, 4th edition, 1996.

[34] M. U. Dianzani, G. Muzio, M. E. Biocca, and R. A. Canuto, "Lipid peroxidation in fatty liver induced by caffeine in rats," International Journal of Tissue Reactions, vol. 13, no. 2, pp. 7985, 1991.

[35] E. Casiglia, P. Spolaore, G. Inocchio, and B. Ambrosio, "Unexpected effects of coffee consumption on liver enzymes," European Journal of Epidemiology, vol. 9, no. 3, pp. 293-297, 1993.

[36] V. Manne and S. Saab, "Coffee as modulator of liver injury: fact and fiction," Clinical Liver Disease, vol. 6, no. 6, pp. 139-141, 2015.

[37] S. Almer and R. Olosson, "The AST/ALT ratio as an indicator of corrhosis in patients with PBC," Liver International, vol. 26, no. 7, pp. 840-845, 2006.

[38] R. Urgert, A. G. M. Schulz, and M. B. Katan, "Effects of cafestol and kahweol from coffee grounds on serum lipids and serum liver enzymes in humans," The American Journal of Clinical Nutrition, vol. 61, no. 1, pp. 149-154, 1995.

[39] P. Fried, "A comparison of the effects of prenatal exposure to tobacco, alcohol, cannabis and caffeine on birth size and subsequent growth," Neurotoxicology and Teratology, vol. 9, pp. 79-84, 1992.

[40] H. M. Salahdeen, A. O. Omoaghe, G. O. Isehunwa, B. A. Murtala, and A. R. A. Alada, "Gas chromatography mass spectrometry (GC-MS) analysis of ethanolic extracts of kolanut (Cola nitida) (vent) and its toxicity studies in rats," Journal of Medicinal Plants Research, vol. 9, no. 3, pp. 56-70, 2015.

[41] A. J. Onuegbu, J. M. Olisekodiaka, O. E. Adebolu, A. Adesiyan, and O. E. Ayodele, "Coffee consumption could affect the activity of some liver enzymes and other biochemical parameters in healthy drinkers," Medical Principles and Practice, vol. 20, no. 6, pp. 514-518, 2011.

[42] O. C. Aloy-Amadi, J. Nnodim, H. Okorie, C. Ogbuokiri, and H. Uduji, "The effect of coffee consumption on liver enzymes and bilirubin in healthy subjects," Journal of Current Research in Science, vol. 1, no. 2, pp. 104-108, 2013.

[43] O. T. Kolawole, M. O. Akiibinu, and M. A. Akanji, "Assessment of the effect of aqueous extract of calyx of Hibiscus sabdariffa on some biochemical indices of renal function in rats," International Journal of Pharma Sciences, vol. 4, no. 3, pp. 587-590, 2014. 
[44] J. O. Adebayo, M. T. Yakubu, E. C. Egwim, V. B. Owoyele, and B. U. Enaibe, "Effect of ethanolic extract of Khaya senegalensis on some biochemical parameters of rat kidney," Journal of Ethnopharmacology, vol. 88, no. 1, pp. 69-72, 2003.

[45] H. A. Harper, Review of Physiological Chemistry, Large Medical, 15th edition, 1975.

[46] B. A. Amadi, E. N. Agomuo, and M. K. C. Duru, "Toxicological studies of Asmina triloba leaves on haematology, liver, kidney using rat model," International Science Research Journal, vol. 4, no. 2, pp. 11-17, 2013.

[47] E. Wough, G. Anne, and B. Allison, Anatomy and Physiology in Health and Illness, Churchill Livingstone Elsevier, 10th edition, 2007.

[48] M. Geethavani and R. Rameswarudu, "Effect of caffeine on serum and urinary electrolytes," International Journal of Scientific and Research Publications, vol. 4, pp. 2250-3153, 2014.

[49] L. E. Armstrong, "Caffeine, body fluid-electrolyte balance, and exercise performance," International Journal of Sport Nutrition and Exercise Metabolism, vol. 12, no. 2, pp. 189-206, 2002.

[50] L. E. Armstrong, D. J. Casa, C. M. Maresh, and M. S. Ganio, "Caffeine, fluid-electrolyte balance, temperature regulation, and exercise-heat tolerance," Exercise and Sport Sciences Reviews, vol. 35, no. 3, pp. 135-140, 2007.

[51] M. N. M. Alves, W. M. Ferrari-Auarek, K. M. C. Pinto et al., "Effects of caffeine and tryptophan on rectal temperature, metabolism, total exercise time, rate of perceived exertion and heart rate," Brazilian Journal of Medical and Biological Research, vol. 28, no. 6, pp. 705-709, 1995.

[52] D. G. Shirley, S. J. Walter, and F. H. Noormohamed, "Natriuretic effect of caffeine: assessment of segmental sodium reabsorption in humans," Clinical Science, vol. 103, no. 5, pp. 461-466, 2002.

[53] A. P. Passmore, G. B. Kondowe, and G. D. Johnston, "Renal and cardiovascular effects of caffeine: A Dose-Response Study," Clinical Science, vol. 72, no. 6, pp. 749-756, 1987.

[54] A. V. Hoff-Brand and J. E. Pettit, Haematological Parameters in Essentials of Haematology, Blackwell Science, 4th edition, 2000.

[55] M. T. Yakubu, M. A. Akanji, and A. T. Oladiji, "Haematological evaluation in male albino rats following chronic administration of aqueous extract of Fadogia agrestis stem," Pharmacognosy Magazine, vol. 3, article 34, 2007.

[56] A. H. Adebayo, A. O. Abolaji, T. K. Opata, and I. K. Adegbenro, "Effects of ethanolic leaf extract of Chrysophyllum albidum G. on biochemical and haematological parameters of albino Wistar rats," African Journal of Biotechnology, vol. 9, no. 14, pp. 21452150, 2010.

[57] I. Celik and H. Suzek, "The hematological effects of methyl parathion in rats," Journal of Hazardous Materials, vol. 153, no. 3, pp. 1117-1121, 2008.

[58] J. O. Adebayo, A. A. Adesokan, L. A. Olatunji, D. O. Buoro, and A. O. Soladoye, "Effect of ethanolic extract of Bougainvillea spectabilis leaves on haematological and serum lipid variables in ratsitm," Biokemistri, vol. 17, no. 1, pp. 45-50, 2005.

[59] D. I. Hassan, D. M. Ogah, N. D. Yusuf, M. M. Musa, and G. M. Saidu, "The effect of acute and chronic (short and long term) oral administrations of black pepper (Piper guineense) aqueous extract on the body weight and haematological values of albinoWistar rat," Journal of Medicinal Plants Research, vol. 4, no. 2, pp. 1122-1125, 2010.

[60] C. Keele, A. Neil, and N. Joels, Sampson Wright's Applied Physiology, Oxford University Press, Oxford, UK, 13th edition, 1983.
[61] N. Yehya, "Mechanism, efficacy and safety of an ephedrine, caffeine, and asprin combination in the treatment of obesity," Nutrition Bytes, vol. 7, pp. 1-5, 2001.

[62] G. Zheng, K. Sayam, T. Okubo, L. R. Juneja, and I. Oguni, "Anti-obesity effects of three major components of green tea, catechins, caffeine and theanine, in mice," In Vivo, vol. 18, no. 1, pp. 55-62, 2004.

[63] W.-T. Cheung, C.-M. Lee, and T.-B. Ng, "Potentiation of the anti-lipolytic effect of 2-chloroadenosine after chronic caffeine treatment," Pharmacology, vol. 36, no. 5, pp. 331-339, 1988.

[64] K. Muroyama, S. Murosaki, Y. Yamamoto, H. Odaka, H. C. Chung, and M. Miyoshi, "Anti-obesity effects of a mixture of thiamin, arginine, caffeine, and citric acid in non-insulin dependent diabetic KK mice," Journal of Nutritional Science and Vitaminology, vol. 49, no. 1, pp. 56-63, 2003.

[65] S. B. Choi, C. H. Park, and S. Park, "Effect of cola intake on insulin resistance in moderate fat-fed weaning male rats," Journal of Nutritional Biochemistry, vol. 13, no. 12, pp. 727-733, 2002.

[66] L.-K. Han, T. Takaku, J. Li, Y. Kimura, and H. Okuda, "Antiobesity action of oolong tea," International Journal of Obesity, vol. 23, no. 1, pp. 98-105, 1999.

[67] D. J. Naismith, P. A. Akinyanju, and J. Yudkin, "Influence of caffeine-containing beverage on the growth, food utilization and plasma lipids of the rat," Journal of Nutrition, vol. 97, no. 3, pp. 375-381, 1969.

[68] H.-P. Würzner, E. Lindström, L. Vuataz, and H. Luginbühl, “A 2 -year feeding study of instant coffees in rats. I. Body weight, food consumption, haematological parameters and plasma chemistry," Food and Cosmetics Toxicology, vol. 15, no. 1, pp. 716, 1977. 

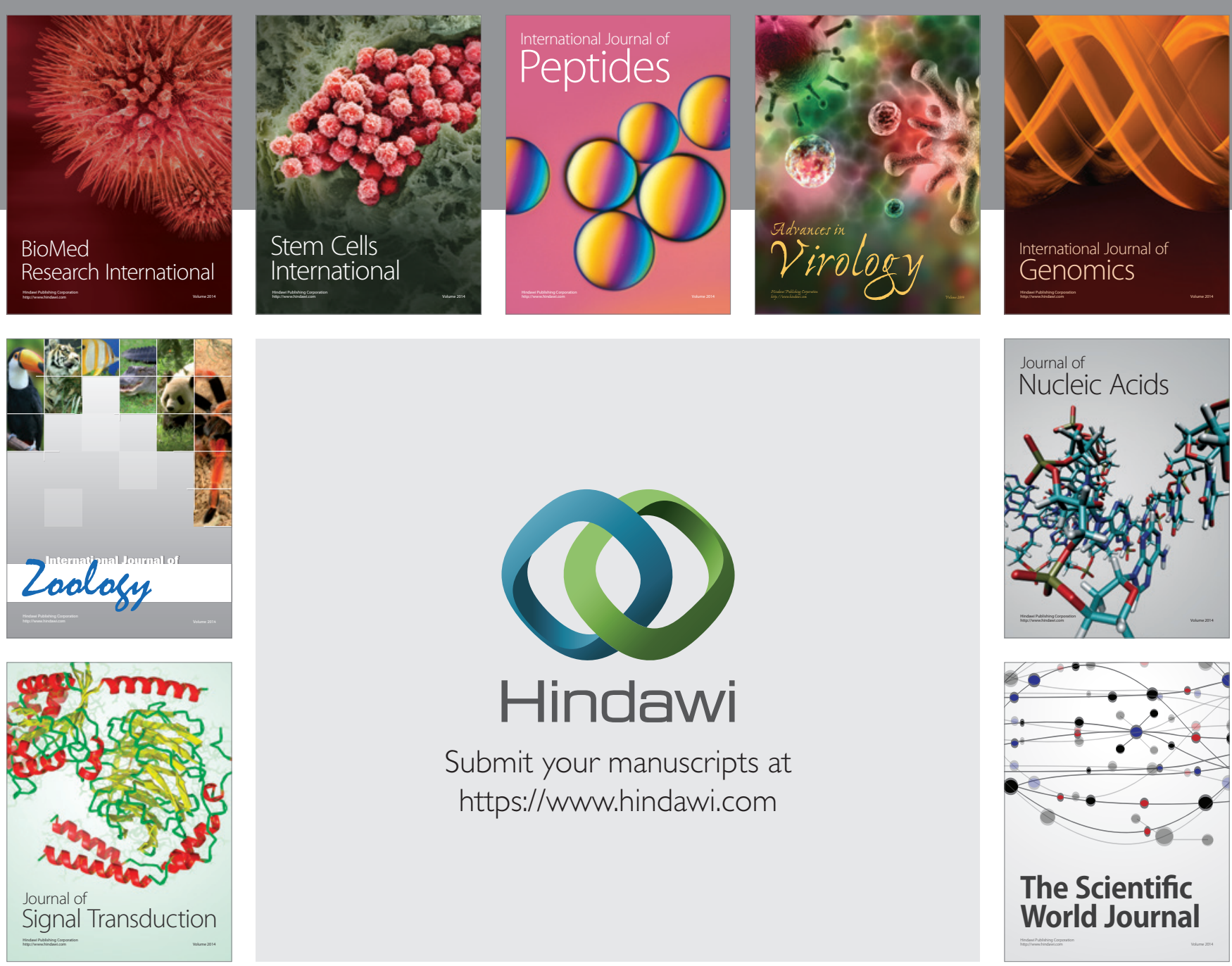

Submit your manuscripts at

https://www.hindawi.com
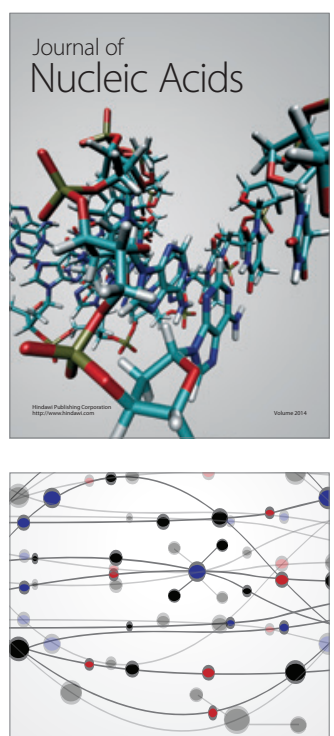

The Scientific World Journal
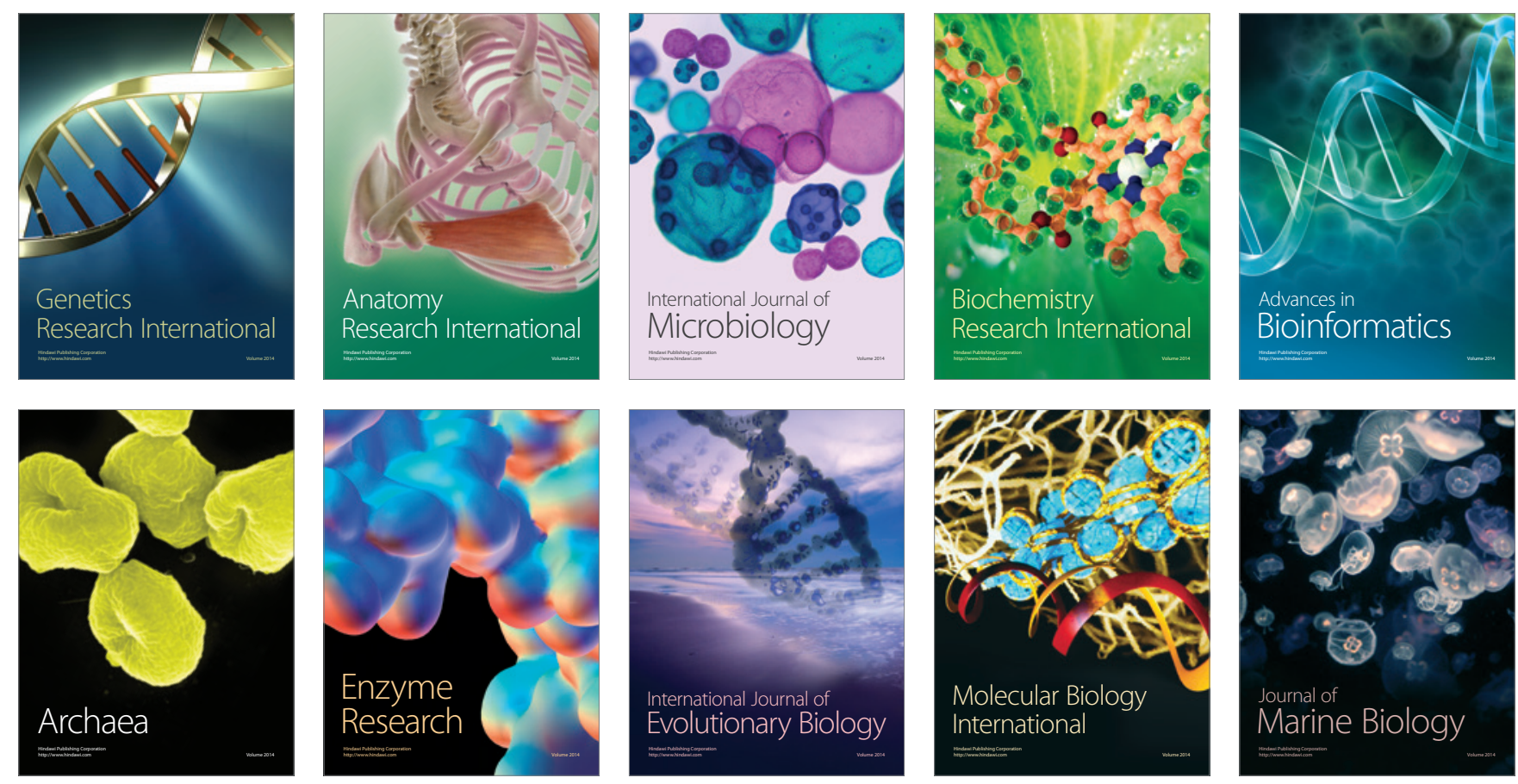